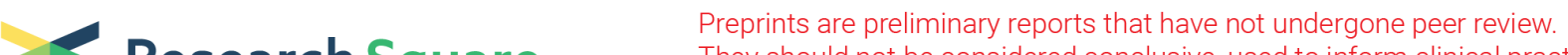

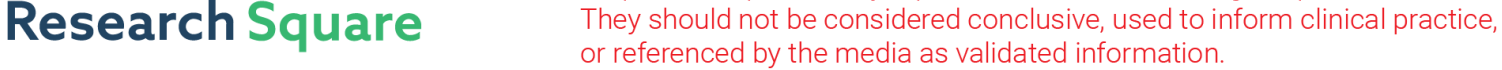 \\ Drivers of Carbon Flux in Drip Irrigation Maize Fields in Northwest China
}

Hui Guo

China Agricultural University

Sien Li ( $\square$ lisien@163.com )

China Agricultural University https://orcid.org/0000-0002-9460-7449

\section{Fuk-Ling Wong}

Chinese unveristy of Hong Kong

\section{Shujing Qin}

China Agricultural University

\section{Yahui Wang}

China Agricultural University

\section{Danni Yang}

China Agricultural University

\section{Hon-Ming Lam}

chinese university of Hong Kong

\section{Research}

Keywords: carbon flux, drip-irrigated maize field, gross primary productivity, net ecosystem productivity, ecosystem respiration, net biome productivity

Posted Date: November 11th, 2020

DOl: https://doi.org/10.21203/rs.3.rs-101488/v1

License: (c) (1) This work is licensed under a Creative Commons Attribution 4.0 International License. Read Full License

Version of Record: A version of this preprint was published at Carbon Balance and Management on April 30th, 2021. See the published version at https://doi.org/10.1186/s13021-021-00176-5. 


\section{Drivers of carbon flux in drip irrigation maize fields in northwest China}

2 Hui Guo ${ }^{1}$, Sien $\mathrm{Li}^{* 1}$, Fuk-Ling Wong ${ }^{2}$, Shujing Qin ${ }^{1}$, Yahui Wang ${ }^{1}$, Danni Yang ${ }^{1}$ Hon-Ming Lam ${ }^{2}$

$3{ }^{1}$ Center for Agricultural Water Research in China, China Agricultural University, Beijing, 100083,

4 China

$5 \quad{ }^{2}$ Center of Soybean Research of the State Key Laboratory of Agrobiotechnology and School of Life

6 Sciences, The Chinese University of Hong Kong, Hong Kong Special Administrative Region, China

9 Received:

10 Accepted:

11

$12 *$ Corresponding authors:

13 Dr. Sien Li (email: lisien@ cau.edu.cn);

14 Prof. Hon-Ming Lam (email: honming@ cuhk.edu.hk) 
Abstract

Background: Under the escalating threat to sustainable development from the global increase in carbon dioxide concentrations, the variations in carbon flux in the farmland ecosystem and their influencing factors have attracted global attention. Over the past few decades, with the development of eddy covariance technology, the carbon fluxes of forests and grasslands have been determined in many countries. However, studies are very limited for the arid regions in northwestern China, which covers a large area where a mixed mode of agriculture and grazing is practiced.

Results: To study the effects of drip irrigation on the net ecosystem productivity (NEE), ecosystem respiration (ER), gross primary production (GPP) and net biome productivity (NBP) in the arid regions of northwestern China, we measured the carbon flux annually from 2014 to 2018 using an eddy covariance system. Our results showed that the maize field carbon flux exhibited single-peak seasonal patterns during the growing seasons. During 2014-2018, the NEE, ER and GPP of the drip-irrigated maize field ranged between -407 -729 $\mathrm{g} \mathrm{C} \mathrm{m}^{-2}$, 485.46 975.46 $\mathrm{g} \mathrm{C} \mathrm{m}^{-2}$, and 1068.23 1705.30 $\mathrm{g} \mathrm{C} \mathrm{m}^{-2}$. In four of the five study years, the ER released back to the atmosphere was just over half of the carbon fixed by photosynthesis. The mean daily NEE, ER and GPP were significantly correlated with the net radiation $(\mathrm{Rn})$, air temperature $(\mathrm{Ta})$, leaf area index (LAI) and soil moisture (SWC). The results of path analysis showed that leaf area index is the main driving force of seasonal variation of carbon flux. When harvested removals were considered, the annual NBP was -234 $\mathrm{g} \mathrm{C} \mathrm{m}^{-2}$, and the drip-irrigated maize field was a carbon source.

Conclusions: This study shows the variation and influencing factors of NEE, ER and GPP in the growth period of spring maize under film drip irrigation in arid areas of northwest China. The ecosystem was a carbon sink before maize harvest, but it was converted into a carbon source considering the carbon emissions after harvest. The variation of carbon flux was influenced by both 
38 environmental and vegetation factors, and its leaf area index was the main driver that affects the 39 seasonal variation of carbon flux.

40 Key words: carbon flux; drip-irrigated maize field; gross primary productivity; net ecosystem 41 productivity; ecosystem respiration; net biome productivity 


\section{Background}

With the increasing global atmospheric carbon dioxide $\left(\mathrm{CO}_{2}\right)$ concentration, the carbon cycle has become a hot issue in all fields of research. According to FAO statistics, croplands account for approximately $11 \%$ of the world's total land area (Food and Agriculture Organization, 2001). The carbon fluxes in farmland ecosystems are directly affected by human activities, such as irrigation methods, planting patterns and agronomic measures, and these activities in turn influence global carbon fluxes due to the relatively high percentage of land areas devoted to farming (Han et al., 2007; Suddick et al., 2013; Li et al., 2018). Therefore, reducing carbon emissions from farmland ecosystems can have a significant impact on mitigating climate change. In agriculture, to date, reducing $\mathrm{CO}_{2}$ emissions has primarily meant prohibiting the burning of straw and other crop wastes as well as changing farming practices (Smith, 2004; Ciais et al., 2010; Lal, 2020; Lal et al., 2018). In recent years, the fluctuation in farmland ecosystem carbon emissions has become a major concern (Janssens et al., 2005; Kutsch et al., 2010; Schulze et al., 2010). Eddy covariance system is an observation technique based on the theory of atmospheric turbulence, which can be used to measure the earth-air exchange process. With the development of eddy covariance technology over a long period of time, so far, technicians have developed a high-precision eddy covariance system, which can realize high frequency and long-term observation of water and carbon fluxes. Studying how to maintain the balance in the carbon budget in arid areas in particular has important scientific significance.

1 Carbon flux has obvious daily seasonal variations. Previous studies have shown that the net ecosystem exchange (NEE) exhibits clear daily variations, generally following a "U" curve over the course of the day with a downward flux (Carrara et al., 2003). With respect to seasonal variations, the NEE is closely related to crop growth (Schmidt et al., 2012; Li et al., 2016). Soil respiration or 
ecosystem respiration (ER) varies throughout the day/night cycle, peaking around midday. This pattern is influenced by different latitudes and different environmental conditions. Previous studies have shown that the maximum respiration value generally occurred at noon, while the minimum value generally occurred in the early morning (Zhang et al., 2003; Wang et al., 2006). Gross primary production (GPP) is the world's most important mode of carbon flux and is closely related to ER and biomass accumulation (Beer et al., 2010). The daily variation in the GPP follows a " $\Lambda$ " shape, with a sharp peak at noon (Flanage et al., 2002). Factor affecting the carbon flux can be divided into biological and non-biological factors, biological factors mainly refers to the associated with plant growth. The study about carbon flux of grassland found that the canopy greenness and coverage is closely related to the spatial and temporal variations of ecosystem carbon flux (Wagle et al., 2015), and plant growth period length to a certain extent determines the value of carbon flux in different seasons (Du et al., 2019). The response of carbon flux to environmental factors is different. In the early growth stage of grassland in arid regions, precipitation is the main factor affecting net ecosystem exchange (Nakano and Shinoda, 2018).

In recent years, drip irrigation has been actively promoted in the arid areas of northwestern China as a water-saving agricultural technology. Drip irrigation under film can provide a timely and appropriate amount of fertilizer and irrigation according to different needs, and it is one of the important measures used to couple water and fertilizer. According to the published statistics, drip irrigation can save 40 60\% water and 30 50\% fertilizer (Lin et al., 2019). At present, using drip irrigation technology under film has been popularized on more than four million hectares in China, and it has been applied to the cultivation of more than 40 crops, among which wheat, maize, cotton and other major field crops have an average yield increase of more than $30 \%$ (Gu et al., 2017). Drip irrigation under film is expected to replace the traditional method of border irrigation. Gansu 
Province is the largest seed production base for hybrid maize in China. At present, there are few studies on the changes in NEE, ER and GPP in the farmland ecosystem under drip irrigation. Research on the global carbon balance must cover all types of biomes, including maize-production areas in the arid regions of northwestern China.

The purpose of the study is to quantify the NEE, GPP and ER of the maize crop ecosystem in the arid regions of northwestern China using eddy covariance systems. The specific goals are as follows: (1) quantify the seasonal and interannual variations in carbon flux in this region, (2) identify the primary environmental factors affecting the seasonal variations of carbon flux and (3) Quantify the growing season carbon budget of drip-irrigated spring maize fields.

\section{Materials and methods}

\subsection{Site description}

This study was conducted east of Hexi Corridor in the arid area of Northwest China $\left(37^{\circ} 52^{\prime} \mathrm{N}\right.$, $102^{\circ} 50^{\prime} \mathrm{E}, 1,585 \mathrm{~m}$ elevation) at the border of Tengger Desert. This area has a typical continental climate and strong temperature differences among the four seasons. The annual average temperature is $7.8^{\circ} \mathrm{C}$. Water resources are scarce in this region; the annual total precipitation is $160 \mathrm{~mm}$, the annual evaporation is more than $2,000 \mathrm{~mm}$, and the groundwater depth is $40-50 \mathrm{~m}$. The soil in the test area is sandy loam ( $\mathrm{Li}$ et al., 2014). The soil texture at 0-0.8 meters deep is silty loam ( $\mathrm{Li}$ et al., 2013; Li et al., 2015), the average soil dry bulk is $1.52 \mathrm{~g} \mathrm{~cm}^{-3}$, and the average field capacity is 0.29 $\mathrm{m}^{3} \mathrm{~m}^{-3}$. Before maize sowing, the $\mathrm{PH}$ of $0-30 \mathrm{~cm}$ in the experimental area was 8.1 , and SOC was $9.6 \mathrm{~g} / \mathrm{kg}$. The entire experimental area has been cultivated for many years, its length is $400 \mathrm{~m}$ and its width is $200 \mathrm{~m}$. The crop cultivated here for seed production is spring maize, and it is sown in late April and harvested in mid-September. The irrigation method is drip irrigation under film mulch. The irrigation and fertilization conditions from 2014 to 2018 are shown in Table 1 and Table 2 . 
Table 1 and Table 2 goes here, please

\subsection{Flux and climatic-factor measurements}

surface and the atmosphere, eddy covariance technology has become increasingly refined after decades of theoretical development and practical application (Baldocchi et al., 1988). An open-path approximately 8 ha. The eddy covariance system consisted of an open-path infrared gas analyzer (EC150, Campbell Scientific Inc., USA) and a three-dimensional anemometer (CSAT3, Campbell Scientific Inc., USA), both installed at a height of $3 \mathrm{~m}$ above the ground.

Routine meteorological factors were measured simultaneously. Air temperature and relative humidity were measured by a temperature and humidity probe at $3 \mathrm{~m}$ (HMP155A, CSI, USA). Radiation was monitored by a radiation meter (CNR4, Kipp \& Zonen, Holland). Soil temperature probes (109L, Campbell Scientific Inc., USA) and soil moisture probes (CS616, Campbell Scientific Inc., USA) were installed to monitor the variations in the soil temperature and soil water content (SWC), respectively, at depths of $20 \mathrm{~cm}, 40 \mathrm{~cm}, 60 \mathrm{~cm}, 80 \mathrm{~cm}$ and $100 \mathrm{~cm}$. All the data were collected with a CR3000 (Campbell Scientific Inc., USA) data logger.

To compensate for the heterogeneity of the underlying vegetation and the error due to instrument installation variability, the raw data were normalized to improve the comparability of the final results. We used Loggernet (Campbell Scientific Inc., USA) to convert the collected data with a sampling frequency of $10 \mathrm{~Hz}$ into data with a frequency of 30 minutes. Eddy Pro software (Li-COR, USA) was then used to perform the stability test, atmospheric turbulence heat verification, and other analyses. The stability of the nighttime atmospheric conditions lowered the data quality. In the case of weak turbulence, the results obtained using the eddy covariance method do not 
accurately reflect the real carbon exchange of the underlying surface. The criterion that reflects the strength of the turbulence in the atmosphere is the frictional wind speed. According to the average values test method (Zhu et al., 2006), for each year from 2014-2018, the critical frictional wind speed values were $0.15 \mathrm{~m} \mathrm{~s}^{-1}, 0.15 \mathrm{~m} \mathrm{~s}^{-1}, 0.20 \mathrm{~m} \mathrm{~s}^{-1}, 0.18 \mathrm{~m} \mathrm{~s}^{-1}$ and $0.12 \mathrm{~m} \mathrm{~s}^{-1}$, respectively. Therefore, when the data were processed, the nighttime carbon flux data associated with a corresponding frictional wind speed that was less than the critical frictional wind speed were removed. The data outliers were removed since they were often caused by external factors such as rain and snow or unstable voltage. In field operations, the installation of the instrument cannot be guaranteed to be absolutely perpendicular to the ground, so the data must be tilted for correction, that is, there must be a coordinate rotation. Finally, a frequency loss correction and an air density correction are required.

Due to instrument failure, extreme weather, power supply issues and data processing errors, there were missing data. To achieve data continuity and integrity, the data were interpolated. Data gaps due to turbulent fluxes or instrument malfunction were divided into short gaps $(<2 \mathrm{~h})$ and long gaps (>2 h) (Gao et al., 2017 $)$. The former were filled by linear interpolation, and the latter were filled using statistical and empirical models (Baldocchi, 2003). The Michaelis-Menten equation was used for daytime data gaps (Michaelis and Menten, 1913):

$$
N E E=E R-\frac{\alpha \bullet P A R \bullet P_{\max }}{P_{\text {max }}+\alpha \bullet P_{\max }}
$$

where $E R$ is the dark respiration, $P A R$ is the photosynthetically active ra diation, $\alpha$ (umol $\mathrm{CO}_{2}$ $\mu \mathrm{mol} \mathrm{PAR}^{-1}$ ) is the apparent quantum efficiency,and $P_{\max }\left(\mathrm{umol} \mathrm{CO}_{2} \mathrm{~m}^{-2} \mathrm{~s}^{-1}\right.$ ) is the maximum ecosystem photosynthesis rate.

The vant Hoff equation was used for nighttime data gaps (Collatz et al., 1991): 
157 where $E R_{r e f}$ is the reference ER at $10^{\circ} \mathrm{C}, B$ is the regression parameter, $T_{s}$ is the surface temperature 158 and $T_{r e f}$ is the reference surface temperature at $10^{\circ} \mathrm{C}$.

159

\subsection{Calculation of the leaf area index (LAI)}

The leaf surface area was measured every seven to ten days from the seedling stage to crop harvest. In the field, we chose six different locations with nine representative plants at each site. A measuring tape (Minimum scale: $\mathrm{mm}$ ) was used to measure the length and width of each leaf. The LAI of the maize leaves can then be obtained using the following formula (Eq. 1) (Guo et al., 2019):

$$
L A I=0.74 \times \frac{\sum_{i=1}^{n} L_{i \times} W_{i}}{D \times S}
$$

where $L A I$ is the leaf area index of maize, 0.74 is the empirical constant, $L i$ is the length of leaf $i, W i$ is the width of leaf $i$, and $D$ and $S$ are the distance between two rows and the space between two plants, respectively.

\subsection{Flux partitioning}

NEE is the net ecosystem exchange (it has a negative value in this context, representing net $\mathrm{CO}_{2}$ fixation by the ecosystem), and it is the sum of ER and GPP. GPP represents the amount of $\mathrm{CO}_{2}$ assimilated by the maize plants during photosynthesis. ER includes both autotrophic and heterotrophic respiration (Buchmann, 2000). Autotrophic respiration includes the respiration of both the underground and aerial parts of the maize plant, and heterotrophic respiration refers to the respiration of the soil organisms.

Crops do not conduct photosynthesis at night, i.e., GPP $=0$. Therefore, the NEE measured by the eddy covariance system at night is the ER of the farmland ecosystem. Once the relationship 
between the nighttime NEE and surface temperature (Ts) was established, the daytime ER was obtained by plugging the daytime $\mathrm{T}_{\mathrm{s}}$ data into the equation.

The most commonly used method is to use the respiratory model to interpolate the missing data. We used the van't Hoff model to simulate the nighttime $\mathrm{CO}_{2}$ flux of the maize with drip irrigation under film mulch as equation (2).

The difference between the NEE and the calculated ER is GPP.

$$
G P P=E R-N E E
$$

\subsection{Net biome productivity}

Net biome productivity (NBP) is defined as:

$$
N B P=C_{i}-C_{e}-N E E
$$

where $C_{i}$ is imported carbon, $C_{e}$ is exported carbon. When the value of NBP is positive, it means the ecosystem is a carbon sink. Otherwise, it is the carbon source.

The amount of exported carbon can be calculated based measured data for biomass, as follows:

$$
C_{e}=D_{g} * a_{1}+D_{c} * a_{2}+D_{l} * a_{3}+D_{s} * a_{4}
$$

where $D_{g}$ is the dry grain, $D_{c}$ the dry cob, $D_{l}$ the dry leaf and $D_{s}$ the dry stem, $a_{1}, a_{2} a_{3}$ and $a_{4}$ is the carbon percentage of different organs, the values of $a_{1}, a_{2} a_{3}$ and $a_{4}$ were $0.447,0.468,0.452$ and 0.452, respectively (Jans et al., 2010; Wang et al., 2015). In our experimental area, the grain and cob were harvested completely, the roots was left in the field, and about $10 \%$ of the leaves and stems were left in the field. The values of $D_{g}, D_{c}, D_{l}, D_{s}$ and $C_{e}$ are shown in Table 3.

\section{Table 3 goes here, please}

\subsection{Statistical analysis}

All the statistical analyses were performed using SPSS for Windows Software (Version 18.0, SPSS Inc., Chicago, IL, USA). Simple linear regression was used to evaluate the relationships between 
daily NEE, ER and GPP. Multiple regression analysis was used to analyze the relationships between

202 various environmental factors ans leaf area index and NEE, ER and GPP.

\section{$203 \quad 3$ Results}

\subsection{Seasonal variations in meteorological and vegetation factors}

Figure 1 shows the seasonal variation characteristics of net radiation $(\mathrm{Rn})$, air temperature (Ta) saturated water vapor pressure difference (VPD), soil water content at 0-20 $\mathrm{cm}$ (SWC) and precipitation (P) and irrigation (I) in the study site from 2014 to 2018.

The seasonal fluctuations in Rn were small. Rn remained at a high level from May to August but began to decline slowly after September (Figure 1(a)). The average Rn over the entire growing period were $141.14,150.26,136.51,132.28$ and $133.27 \mathrm{w} \mathrm{m}^{-2}$ in $2014 \sim 2018$, respectively. Among then, the average $\mathrm{Rn}$ values peaked at the heading stage or shooting stage. The average air temperatures for each of the five growing seasons were $19.02,19.12,21.01,19.58$ and $20.14^{\circ} \mathrm{C}$, respectively (Figure 1(b)). During maize growth and development, the pattern of temperature during each growth period differed slightly among years. In 2014, 2017 and 2018, the air temperature peaked during the heading stage, while in 2015 and 2016, it peaked during the filling stage. The difference in the VPD between the years was rather small. However, in 2017, the seasonal average VPD was the highest because that year had the lowest amount of precipitation and irrigation, which led to dry air. The soil water content for the five growing seasons were consistent with precipitation and irrigation events, and the values were $0.17,0.20,0.23,0.25$ and $0.24 \mathrm{~cm}^{3}$ $\mathrm{cm}^{-3}$, respectively. The sum of precipitation and irrigation were $545.40 \mathrm{~mm}, 519.40 \mathrm{~mm}, 542.22$ $\mathrm{mm}, 502.28 \mathrm{~mm}$ and $578.32 \mathrm{~mm}$, respectively. Since this is an arid region, precipitation played a very minor role in supplying the water required for crop growth in comparison to irrigation. 
Figure 2 shows the seasonal variation patterns in the maize LAI from 2014 to 2018. Throughout

the growing season, the change in LAI assumed a parabolic curve. Starting from the seedling stage,

LAI increased with the crop growth and peaked at the heading stage. During the mid and late stages of maize growth, LAI decreased significantly because of the special management measures that were implemented for seed maize, i.e., after pollination, the male plants were cut, which led to a significant decrease in LAI. For each year from 2014 to 2018, the maximum LAI values were 3.09, 5.53, 5.28, 4.26 and $4.93 \mathrm{~m}^{2} \mathrm{~m}^{-2}$, respectively. The maximum LAI for 2015 was the highest among all five years, which was primarily due to the best crop growth, which was observed in 2015.

\section{Figure 2 goes here, please}

\subsection{Seasonal and interannual variations of NEE, ER and GPP}

The seasonal dynamics of NEE, GPP and ER during 2014-2018 are illustrated in Figure 3(a). With the growth of the maize and variations of climate, NEE, ER and GPP showed clear seasonality. The variations in ER were relatively weak, whereas large fluctuations in GPP during crop growth were frequent. In the early growth stage, ER was low, mainly due to the low air temperature. Daily ER increased significantly in mid-June due to both the increase in air temperature and crop growth. The maximum value of ER occurred during the heading or filling stage; with crop decline and the reduction of temperature, ER began to slowly decline. Daily GPP and NEE peaked in the heading stage in all five years; at this stage, leaf area reached its maximum value, and the meteorological conditions were optimal for growth.

During the early stage of crop growth, i.e., from April to May, the NEE was positive, indicating that the total respiration per sq. m. for the maize field was higher than the total photosynthesis. Thus, the maize field released $\mathrm{CO}_{2}$ into the atmosphere. During the fast-growth stage, i.e., from June to August, the total photosynthesis exceeded the respiration, and the NEE peaked over a range 
from -10 to $-20 \mathrm{~g} \mathrm{C} \mathrm{m}^{-2} \mathrm{~d}^{-1}$ between 2014 and 2018. Thus, at this stage of growth, maize field was most capable of sequesturing $\mathrm{CO}_{2}$ from the atmosphere. During the late stage of crop growth, i.e., from September to October, the NEE value gradually decreased but remained negative, indicating that the carbon absorption capacity of the maize field was weak during this time (Figure 3). The findings demonstrate that during the early growth stage, the maize field released $\mathrm{CO}_{2}$ into the atmosphere. Its $\mathrm{CO}_{2}$ absorption capacity gradually increased as the growing season progressed, reaching a peak and then slowly declining at the end of the growing season. From 2014 to 2018, the GPP and NEE values decreased significantly on rainy or cloudy days when the photosynthetic

\section{Figure 3 goes here, please}

NEE, ER and GPP were not subjected to large inter-annual variability (Table 4). On the annual scale, comparing to NEE and GPP, the cumulative ER in five years showed a more significant interannual variability, and the value of $\mathrm{CV}$ was 0.22 . The cumulative NEE, ER and GPP for the 5 years ranged from to -406.76 to $-729.89 \mathrm{~g} \mathrm{C} \mathrm{m}^{-2}, 661.84$ to $975.46 \mathrm{~g} \mathrm{C} \mathrm{m}^{-2}$ and 1705.30 to 1068.63 $\mathrm{g} \mathrm{C} \mathrm{m}^{-2}$, respectively ( Table 4). The maximum value of NEE, ER, and GPP occurred in the bloom period of crop growth, and the coefficient of variation was similar to the annual, with CV values of $20 \%, 24 \%$, and $14 \%$, respectively.

\section{Table 4 goes here, please}

The ratio of the ER to the GPP ranged from 44 to $62 \%$ in growing seasons of the five years, indicating that over half of the carbon fixed via photosynthesis was released back to the atmosphere by respiration. In the early stage of crop growth, the photosynthetic capacity of maize was relatively weak, and the field was mainly dominated by soil respiration. Therefore, the ratio of ER/GPP was relatively high at the seedling stage, exceeding $100 \%$ in four of five years. As crops growing and 
development, the ability to photosynthesize increased, and the ratio begins to decline slowly. However, at the later stage of growth, the aging and falling of leaves caused by crop ripening increased the ER/GPP ratio. The year 2014 was an exception in that the ER/GPP ratio was below $50 \%$. During the seedling stage, the ER/GPP ratio exceeded $100 \%$ in all years except 2015, which indicated that the amount of $\mathrm{CO}_{2}$ released into the atmosphere by ER was greater than the amount fixed by photosynthesis. The five-year mean values of ER/GPP at different fertility stages were $119 \%, 45 \%, 43 \%, 55 \%$ and 68\%, respectively (Figure 4).

\section{Figure 4 goes here, please}

We used a linear regression model to explore the relationship between NEE, ER and GPP. Figure 6 showed that the variation of NEE and ER were significantly correlated with GPP, and both R2 were higher $(\mathrm{P}<0.0001)$. The value of NEE decreased with the increase of GPP, which indicated that the carbon sequestration capacity of crops increased with the increase of photosynthetic capacity. ER increased with the increase of GPP, which also indicated that when the photosynthetic capacity of crops increased, the respiration capacity of maize fields also increased. According to the regression equation (Figure 5), the variation of GPP contributed 68\% and 32\% to the variation of NEE and ER, respectively.

\section{Figure 5 goes here, please}

\subsection{Relationships between environmental variables and NEE, ER and GPP}

Analyses of the relationships between each of NEE, ER and GPP and various environmental factors and plant physiology are key to interpreting the seasonal and interannual variations in NEE, ER and GPP in maize fields. The results from the statistical analyses of daily average NEE, ER, GPP, Rn, Ta, VPD, SWC, IP and LAI from 2014 to 2018 are shown in Table 5. 
$293 T_{a}$ and LAI increased and decreased, the smaller the negative value of NEE was, the stronger the ability to fix $\mathrm{CO}_{2}$ in the atmosphere was. VPD in 2016 and 2017 also showed a very significant correlation with NEE ( $\mathrm{p}<0.01$ ), and SWC also had a significant impact on NEE in 2014, 2016 and 2018. However, the effect of irrigation and precipitation on NEE was not significant. The research results on ER showed that during the growing season of maize from 2014 to 2018, ER was significantly positively correlated with $\mathrm{Rn}$, Ta and LAI $(\mathrm{p}<0.01)$. The seasonal variations of ER in 2015-2018 were also influenced by VPD ( $\mathrm{p}<0.01)$. In addition to 2016, the influence of SWC on ER is also not negligible. Therefore, $\mathrm{Rn}, \mathrm{Ta}$ and LAI have important effects on ecosystem respiration. Examination of the relationships between ER and environment/physiological factors showed high correlation coefficients between ER and Ta and ER and LAI (Table 5), indicating that the ER of the farmland ecosystem is sensitive to crop growth and Ta. With crop growth and development, the ER capacity also increased.

Table 5 goes here, please 
soil water content has a significant effect on GPP. Among all the investigated potential drivers, we found that the leaf area index was the most important controls.

In order to more accurately predict the seasonal variations of NEE, ER and GPP, according to the results in Table 5, we selected the factors with highly significant correlations $(\mathrm{p}<0.01)$ with NEE, ER and GPP for multi-factor fitting. As can be seen from the results in Table 5, when multi-factor regression was adopted, the seasonal variations of NEE, ER and GPP could be well simulated during the growing seasons, among which GPP has the best simulation effect, with goodness of fit values of 0.72-0.78 for NEE, 0.76-0.90 for ER and 0.70-0.90 for GPP (Table 6).

Table 6 goes here, please

\subsection{Carbon budget}

Net biome productivity was analyzed to determine whether drip-irrigated maize fields were carbon sources or carbon sinks. According to equation 5, it can be known that NBP is the difference between the carbon input and the carbon output and the net ecosystem exchange. Since no organic fertilizer was applied in our experimental area, the total input carbon was 0. From 2014 to 2018, the NBP of the maize field in the experiment site was $-165.12,-202.09,-378.55,-192.51$ and $-230.08 \mathrm{~g} \mathrm{C} \mathrm{m}^{-2}$, respectively. In 2016, because the water, fertilizer, light and heat conditions were more suitable for the growing of maize, the maximum yield of maize was $1095 \mathrm{~g} \mathrm{C} \mathrm{m}^{-2}$, so the output of carbon was also the largest.During the drip-irrigated maize field was a carbon source and the average NBP was $-233.77 \mathrm{~g} \mathrm{C} \mathrm{m}^{-2}$ (Figure 7).

Figure 7 goes here, please

\section{Discussion}

\subsection{Factors controlling seasonal variations in carbon flux}


Many studies showed that radiation, air temperature, precipitation, soil moisture content and

LAI are the main factors affecting carbon flux during the growing season in different ecosystems (Alberto et al., 2013). Our study showed that LAI had significant effects on NEE, ER and GPP, which indicated that the growth status of crops plays a crucial role in influencing carbon flux during the growth period (Figure 7). Through path analysis, the study showed that LAI is the leading

\subsection{Annual carbon flux}


360 from published papers to compare NEE of maize among different areas. We compared the NEE of maize among regions with different climate and management practices. Research in the arid region of northwest China, Yingke station observations showed the mean value of NEE in 2007-2008 was -626 $\mathrm{g} \mathrm{C} \mathrm{m}^{-2}$, which was higher than the mean value of $-527.09 \mathrm{~g} \mathrm{C}^{-2}$ during 2014-2018 in our research (Wang et al., 2012). This is due to the fact that the observation time at yingke included fallow periods, whereas our study was conducted only during maize growing season. In Europe,

$\mathrm{NEE}$ in the Netherlands and Italy was $-597 \mathrm{~g} \mathrm{C} \mathrm{m}^{-2}$, respectively, while the value of NEE was -186 $\mathrm{g} \mathrm{C} \mathrm{m}^{-2}$ in France, in Italy the NEE was $-473 \mathrm{~g} \mathrm{C} \mathrm{m}^{-2}$. Due to the different growing environment of maize, there are great differences between maize field NEE. In order to analyze the impact of farmland management measures on carbon fluxes, some researchers have conducted analyses. In Nerbraska, USA, the results of the study showed that the NEE value of irrigated maize was lower than that of rainfed maize (Suyker and Verma, 2012). The results of the study on mulching and non-mulching showed that the NEE of maize field after mulching was smaller, indicating that the mulching could absorb more $\mathrm{CO}_{2}$ from the atmosphere ( $\mathrm{Gao}^{\mathrm{b}}$ et al., 2017)。

Table 6 goes here, please and Lamasquere, France, showed that the ER/GPP ratios in these regions were higher than those in other regions, with both sites having ratios of more than 80\% (Jans et al., 2010; Beziat et al., 2009). Suyker et al. (2012) showed that despite differences in NEE, GPP and ER between irrigated maize

The five-year average ER/GPP ratio was 57\% (Table 4), which is similar to the value of $60 \%$ reported in the Heihe River basin (Wang et al., 2012). Research in the Wageningen, Netherlands, and rain-fed maize, the ER/GPP ratio of both types of maize was 57\% (Suyker et al., 2012). This value is very close to our results. Another study showed that the ratio of ER to GPP in mulching 
spring maize was lower than that in non-mulching spring maize; although film mulching increased ER, GPP also increased (Gao et al., 2017 ${ }^{\text {b }}$. Studies of summer maize in northern China have found that the ratio of ER to GPP was greater in summer maize than in spring maize, exceeding 70\% (Lei and Yang, 2010; Wang et al., 2015).

Farmland is different from forest, when the crops are ripe, crops have to be harvested. Therefore, when determining whether the farmland is a carbon source or a carbon sink, we need to consider the carbon emission exported by harvesting crops. During the growing seasons, $579 \mathrm{~g} \mathrm{C}$ $\mathrm{m}^{-2}$ (Table 3) was sequestered by uptake of $\mathrm{CO}_{2}$ from atmosphere. The amount of carbon exported from field was $813 \mathrm{~g} \mathrm{C} \mathrm{m}^{-2}$ (Table 2). this implies a carbon loss of $234 \mathrm{~g} \mathrm{C} \mathrm{m}^{-2}$ from soil during the growing season. It should be noted that the amount of carbon input to the soil from the harvested residues has been taken into account in the calculation of the carbon output when ploughed into the soil. Compared with other regions, we found that all the other sites except shouyang were represented as carbon sources (NBP is positive) to varying degrees. This was because in shouyang, straw was used for returning to the field, leaving the rest of the field except the seeds. It can be inferred that straw mulching can effectively reduce carbon loss.

The above results show that both growing environment and farmland management measures had significant impacts on carbon fluxes. More than half of the carbon dioxide fixed by crops through photosynthesis was returned to the atmosphere through ecosystem respiration in maize ecosystem. In agriculture, straw mulching can effectively reduce carbon loss.

\section{Conclusion}

We measured the carbon flux annually from 2014 to 2018 using an eddy covariance system. This 5-year study showed that carbon flux exhibited single-peak seasonal patterns during the growing seasons. The ratio of the ER to the GPP ranged from 44 to $62 \%$ in growing seasons of the 
five years, indicating that over half of the carbon fixed via photosynthesis was released back to the atmosphere by respiration. The seasonal vaeiation of GPP significantly affected the variation of NEE and ER in the growing season. Leaf area index was the most significant factor to control the seasonal variation of carbon flux in the growing season, followed by $\mathrm{Rn}$ and Ta. In addition, soil water content has a significant effect on GPP. The 5-year mean values of NEE, ER and GPP in our study were $-527,734$ and $1313 \mathrm{~g} \mathrm{C} \mathrm{m}^{-2}$. Taking into account $\mathrm{C}_{\mathrm{e}}$, the annual NBP was $-234 \mathrm{~g} \mathrm{C} \mathrm{m}^{-2}$. These results confirmed that the use of straw to raise livestocks in the arid areas of northwest China had increased carbon emissions, leading to an increase in carbon dioxide emissions in the region. As the carbon balance of farmland varies greatly, it is highly sensitive to management measures such as tillage, mulching, fertilization and straw mulching. Future research should focus on the carbon fluxes of different farmland systems and their responses to management measures and climate change.

\section{Declaration}

\section{Availability of data and materials}

The observed meteorological data are shown in Figure 1, crop growth information is shown in Figure 2, and carbon flux data is shown in Figure 3.

\section{Competing interests}

We declare that We have no known competing financial interests or personal relationships that could have appeared to influence the work reported in this paper.

\section{Acknowledgments}

The authors would like to thank anonymous reviewers for their constructive commen. And thanks Ms. Jee Yan Chu for copyediting the manuscript.

\section{Authors' contributions}


Sien Li and Hon-Ming Lam conceived and designed the study. Hui Guo conducted the analyses. All 429 authors read and approved the fnal manuscript.

\section{$430 \quad$ Funding}

431 Financial support for this work was provided by the Chinese National Natural Science Fund 432 (51622907, 51621061 and 51879262), the Hong Kong Research Grants Council Area of Excellence 433 Scheme (AoE/M-403/16) and the National Key Research and Development Program of China 434 (2016YFC0400201). Ms. Jee Yan Chu copyedited the manuscript.

\section{Author details}

4361 Center for Agricultural Water Research in China, China Agricultural University, Beijing, 100083, 437 China

2 Center of Soybean Research of the State Key Laboratory of Agrobiotechnology and School of

Life Sciences, The Chinese University of Hong Kong, Hong Kong Special Administrative Region,

China

\section{References}

Alberti, G., Delle Vedove, G., Zuliani, M., Peressotti, A., Castaldi, S., Zerbi, G. 2009. Changes in 
biologically related gases with micro-meteorologicalmicrometeorological methods. Ecology 69 (5), 1331-1340. https://doi.org/10.2307/1941631

Baldocchi, D.D., 2003. Assessing the eddy covariance technique for evaluating carbon dioxide exchange rates of ecosystems: past, present and future. Global Change Biology 9, 479-492. https://doi.org/10.1046/j.1365-2486.2003.00629.x

Beer, C., Reichstein, M., Tomelleri, E., Ciais, P., Jung, M., Carvalhais, N., Bondeau, A. 2010. Terrestrial gross carbon dioxide uptake: global distribution and covariation with climate. Science 329, 834-838. https://doi.org/10.1126/science.1184984

Beziat, ., Ceschia, E., Dedieu, G. 2009. Carbon balance of a three crop succession over two cropland sites in South West France. Agricultural and Forest Meteorology 149(10), 1628-1645. https://doi.org/10.1016/j.agrformet.2009.05.004

Buchmann, N., 2000. Biotic and abiotic factors controlling soil respiration rates in Picea abies $\begin{array}{lllll}\text { stands. } & \text { Soil } \quad \text { Biology } \quad \& \quad \text { Biochemistry } & \text { 32(11), }\end{array}$ https://doi.org/10.1016/S0038-0717(00)00077-8

Carrara, A., Kowalski, A. S., Neirynck, J., Janssens, I. A., Yuste, J. C., Ceulemans, R., 2003. Net ecosystem co 2, exchange of mixed forest in belgium over 5 years. Agricultural and Forest Meteorology 119(3), 209-227. https://doi.org/10.1016/S0168-1923(03)00120-5

Ciais, P., Wattenbach, M., Vuichard, N., Smith, P., Piao, S.L., Don, A., Luyssaert, S., Janssens, I.A., Bondeau, A., Dechow, R., Leip, A., Smith, P.C., Beer, C., van der Werf, G.R., Gervois, S., Van Oost, K., Tomelleri, E., Freibauer, A., Schulze, E.D., 2010. The European carbon balance. Part 2: Croplands. Global Change Biology 16(5). 1409-1428. https://doi.org/10.1111/j.1365-2486.2009.02055.x

Collatz, G.J., Ball, J.T., Grivet, C., Berry, J.A., 1991. Physiological and environmental regulation of 
stomatal conductance, photosynthesis and transpiration: a model that includes a laminar boundary layer. Agricultural and Forest Meteorology 54 (2-4), 107-136. https:// doi.org/10.1016/0168-1923(91)90002-8.

Du, Q., Liu, H.Z., Li, Y.H., Xu, L.J., Diloksumpun, S., 2019. The effect of phenology on the carbon exchange process in grassland and maize cropland ecosystems across a semiarid area of China. Science of the total environment. 695. https://doi.org/10.1016/j.scitotenv.2019.133868

Food and Agriculture Organization, 2001. Soil carbon sequestration for improved land management. World Soil Resources Reports. Rome, Italy.

Falge, E., Baldocchi, D., Tenhunen, J., Aubinet, M., Bakwin, P., Berbigier, P., Bernhofer, C., Burba, G., Clement, R., Davis, K.J., Elbers, J.A., Goldstein, A.H., Grelle, A., Granier, A., Guomundsson, J., Hollinger, D., Kowalski, A.S., Katul, G., Law, B.E., Malhi, Y., Meyers, T., Monson, R.K,, Munger, J.W., Oechel, W., Paw, K.T., Pilegaard, K., Rannik, U., Rebmann, C., Suyker, A., Valentini, R., Wilson, K., Wofsy, S., 2002. Seasonality of ecosystem respiration and gross primary production as derived from FLUXNET measurements. Agricultural and Forest Meteorology 113(1), 53-74. https://doi.org/10.1016/S0168-1923(02)00102-8

Gao, X., Gu, F.X., Hao, W.P., Mei, X.R., Li, H.R., Gong, D.Z., Mao, L.L., Zhang, Z.G. $2017^{\mathrm{a}}$. Carbon budget of a rainfed spring maize cropland with straw returning on the Loess Plateau, China. Science of the Total Environment 586, 1193-1203. https://doi.org/10.1016/j.scitotenv.2017.02.113

Gao, X., Gu, F.X., Mei, X.R., Hao, W.P., Li, H., Gong, D.Z. 2017b. Carbon exchange of a rainfed spring maize cropland under plastic film mulching with straw returning on the Loess Plateau, China. Catena 158, 198-208. https://doi.org/10.1016/j.catena.2017.07.015

Gonzalez-Real M.M., Martin-Gorriz B., Egea G., Nortes, P.A., Baille A. 2018. Characterization and 
modelling of soil $\mathrm{CO}_{2}$ efflux in old and young irrigated citrus orchards. Catena 162, 376-385. https://doi.org/10.1016/j.catena.2017.10.025

499

500

501

Gu, T., Li, Z.Z., Wu, Y.Q., 2017, China micro irrigation development status and "13 th five year" development prospect. Water saving irrigation(in Chinese) 3, 90-91.

Guo, H., Li, S.E., Kang, S.Z., Du, T.S., Tong, L., Ding, R.S., 2019. Annual ecosystem respiration of maize was primarily driven by crop growth and soil water conditions. Agriculture, Ecosystems \& Environment 272, 254-265. https://doi.org/10.1016/j.agee.2018.11.026

Han, G.X,, Zhou, G.H., Xu, Z.H., Yang, Y., Liu, J.L,, Shi, K.Q., 2007. Soil temperature and biotic factors drive the seasonal variation of soil respiration in a maize (Zea mays L.) Agricultural ecosystem. Plant Soil 291: 15-26. https://doi.org/10.1007/s11104-006-9170-8

Jans, W.W.P., Jacobs, C.M.J., Kruijt, B., Elbers, J.A., Barendse, S., Moors, E.J. 2010. Carbon exchange of a maize (Zea mays L.) crop: Influence of phenology. Agriculture Ecosystems \& Environment 139(s1,3), 316-324. https://doi.org/10.1016/j.agee.2010.06.008

Janssens, I.A., Freibauer, A., Schlamadinger, B., Ceulemans, R., Ciais, P., Dolman, A.J., Heimann, M., Nabuurs, G.J., Smith, P., Valentini, R., Schulze, E.D., 2005. The carbon budget of terrestrial ecosystems at country-scale-a European case study. Biogeosciences 1, 15-26. https://doi.org/10.5194/bg-2-15-2005

Kutsch, W.L., Aubinet, M., Buchmann, N., Smith, P., Osborne, B., Eugster, W., Wattenbach, M., Schrumpf, M., Schulze, E.D., Tomelleri, E., Ceschia, E., Bernhofer, C., Beziat, P., Carrara, A., Di Tommasi, P., Grunwald, T., Jones, M., Magliulo, V., Marloie, O., Moureaux, C., Olioso, A., Sanz, M.J., Saunders, M., Sogaard, H., Ziegler, W., 2010. The net biome production of full crop rotations in Europe. Agriculture Ecosystems \& Environment 139(3), 336-345. https://doi.org/10.1016/j.agee.2010.07.016 
Lal, R., 2020. Managing soils for resolving the conflict between agriculture and nature: The hard talk. European Journal of Soil Science 71(1), 1-9. https://doi.org/10.1111/ejss.12857 n/a.

Lal, R., Smith, P., Jungkunst, H.F., Mitsch, W.J., Lehmann, J., Nair, P.K.R., McBratney, A.B., de Moraes Sá, J.C., Schneider, J., Zinn, Y.L., Skorupa, A.L.A., Zhang, H.-L., Minasny, B., Srinivasrao, C., Ravindranath, N.H., 2018. The carbon sequestration potential of terrestrial ecosystems. Journal of Soil and Water Conservation 73, 145A-152A. https://doi.org/10.2489/jswc.73.6.145A

Lei, H.M., Yang, D.W. 2010. Seasonal and interannual variations in carbon dioxide exchange over a cropland in the North China Plain. Global Change Biology 16(11), 2944-2957. https://doi.org/10.1046/j.1365-2486.2000.00291.x

Li, H.Q., Zhang, F.W., Li, Y.N,. Wang, J.B., Zhang, L.M., Zhao, L., Cao, G.M., Zhao, X.Q., Du, M.Y., 2016. Seasonal and inter-annual variations in $\mathrm{CO}_{2}$ fluxes over 10 years in an alpine shrubland on the Qinghai-Tibetan Plateau, China. Agricultural and Forest Meteorology 228-229(228), 95-103. https://doi.org/10.1016/j.agrformet.2016.06.020

Li, S.E., Hao, X.M., Du, T.S., Ton,g L., Zhang, J., Kang, S.Z. 2013, A coupled surface resistance model to estimate crop evapotranspiration in arid region of northwest China. Hydrological Processes 28(4):2312-2323. https://doi.org/10.1002/hyp.9768

Li, S.E., Hao, X.M, Du, T.S., Tong, L., Zhang, J.H., Kang, S.Z., 2014, A coupled surface resistance model to estimate crop evapotranspiration in arid region of northwest China. Hydrological Processes 28, 2312-2323. https://doi.org/10.1002/hyp.9768

Li, S.E., Zhang L, Kang, S.Z., Tong, L., Du, T.S., Hao, X.M., Zhao, P. 2015, Comparison of several surface resistance models for estimating crop evapotranspiration over the entire growing season in arid regions. Agricultural and Forest Meteorology 208:1-15. 
Li, J.W., Jian, S.Y., de Koff, J.P., Lane, C.S., Wang, G.S., Mayes, M.A,, Hui, D.F., 2018. Differential effects of warming and nitrogen fertilization on soil respiration and microbial dynamics in switchgrass croplands. Global Change Biology Bioenergy 10:565-576. https://doi.org/10.1111/gcbb.12515

Lin, B.J., Zhang, R., Gao, Y.T., Zhang, S., 2019, Analysis on the Development Status and Countermeasures of High-efficiency Water-saving Irrigation technology in northwest China. Water Resources Planning and Design (in Chinese) 3, 29-33.

Ma, Z.L., Zhao, W.Q., Liu, M., Liu, Q., 2018. Responses of soil respiration and its components to experimental warming in an alpine scrub ecosystem on the eastern Qinghai-Tibet Plateau. Science of the Total Environment 643 643 $1427-1435$. https://doi.org/10.1016/j.scitotenv.2018.06.243

Nakano, T., Shinoda, M., 2018 Interannual variation in net ecosystem CO2 exchange and its climatic controls in a semiarid grassland of Mongolia. Journal of Agricultural Meteorology. 74(2), 92-96. https://doi.org/10.2480/agrmet.D-17-00035

Schmidt, M., Reichenau, T.G., Fiener, P., Schneider, K., 2012. The carbon budget of a winter wheat field: An eddy covariance analysis of seasonal and inter-annual variability. Agricultural and Forest Meteorology 165, 114-126. https://doi.org/10.1016/j.agrformet.2012.05.012

Schulze, E.D., Ciais, P., Luyssaert, S., Schrumpf, M., Janssens, I.A., Thiruchittampalam, B., Theloke, J., Saurat, M., Bringezu, S., Lelieveld, J., Lohila, A., Rebmann, C., Jung, M., Bastviken, D., Abril, G., Grassi, G., Leip, A., Freibauer, A., Kutsch, W., Don, A., Nieschulze, J., Borner, A., Gash, J.H., Dolman, A.J., 2010. The European carbon balance. Part 4: integration of carbon and other trace-gas fluxes. Global Change Biology 16, 1451-1469. 
567 Smith, P., 2004. Carbon sequestration in croplands: the potential in Europe and the global context. European Journal of Agronomy 20, 229-236. https://doi.org/10.1016/j.eja.2003.08.002

Suddick EC, Whitney P, Townsend AR, Davidson EA (2013) The role of nitrogen in climate change and the impacts of nitrogen-climate interactions in the United States: foreword to thematic issue.

Suyker, A.E., Verma, S.B., 2012. Gross primary production and ecosystem respiration of irrigated and rainfed maize-soybean cropping systems over 8 years. Agricultural and Forest Meteorology 165(6), 12-24. https://doi.org/10.1016/j.agrformet.2012.05.021

Tong X., Li J., Nolan R.H., Yu Q., 2017. Biophysical controls of soil respiration in a wheat-maize rotation system in the North China Plain Agricultural and Forest Meteorology, 246:231-240. https://doi.org/10.1016/j.agrformet.2017.07.005

Wagle, P., Gowda, P. H., Northup, B. K., Turner, K. E., Neel, J. P. S., Manjunatha, P., Zhou, Y.T., 2018. Variability in carbon dioxide fluxes among six winter wheat paddocks managed under different tillage and grazing practices. Atmospheric Environment, 185, 100-108. https://doi.org/10.1016/j.atmosenv.2018.05.003

Wagle P., Xiao X., Scott R.L., Kolb T.E., Cook D.R., Brunsell N., Baldocchi D.D., Dennis D., Basara J., Matamala R., Zhou Y.T., Bajgain R.,2015. Biophysical controls on carbon and water vapor fluxes across a grassland climatic gradient in the United States. Agricultural and Forest Meteorology, 214, 293-305. https://doi.org/10.1016/j.agrformet.2015.08.265

Wang, X., Zhou, G.S., Jiang, Y.L., Li, F., 2006. Comparison of soil respiration in broad-leaved Korean pine forest and reclaimed cropland in Changbai Mountains, China. Journal of Plant Ecology 30, 887-893. 
Wang, X.F., Ma, M.G., Huang, G.H., Veroustraete, F., Zhang, Z.H., Song, Y., Tan, J.L. 2012. Vegetation primary production estimation at maize and alpine meadow over the Heihe River Basin, China. International Journal of Applied Earth Observation and Geoinformation 17(s1), 94-101. https://doi.org/10.1016/j.jag.2011.09.009

Wang, Y.Y., Hu, C.S., Dong, W.X., Li, X.X., Zhang, Y.M., Qin, S.P., Oenema, O. 2015. Carbon budget of a winter-wheat and summer-maize rotation cropland in the North China Plain. $\begin{array}{llll}\text { Agriculture } \quad \text { Ecosystems } \quad \& \quad \text { Environment } & 206,\end{array}$ https://doi.org/10.1016/j.agee.2015.03.016

Zhang, X.Z., Liu, Y.F., Zhong, H.P., Ouyang, H., 2003. Daily and seasonal variation of soil respiration of farmland in the Tibetan plateau. Resources Science (in Chinese) 25, 103-107.

Zhu Z.L., Sun X.M., Zhou Y.L., Tian J., Yuan F.G., 2006. Study on the processing method of $\mathrm{CO}_{2}$ eddy covariance flux data of ChinaFLUX network (ChinaFLUX) at night. Science in China(Series D:Earth Sciences)(in Chinese), s1, 34-44. 
Figures

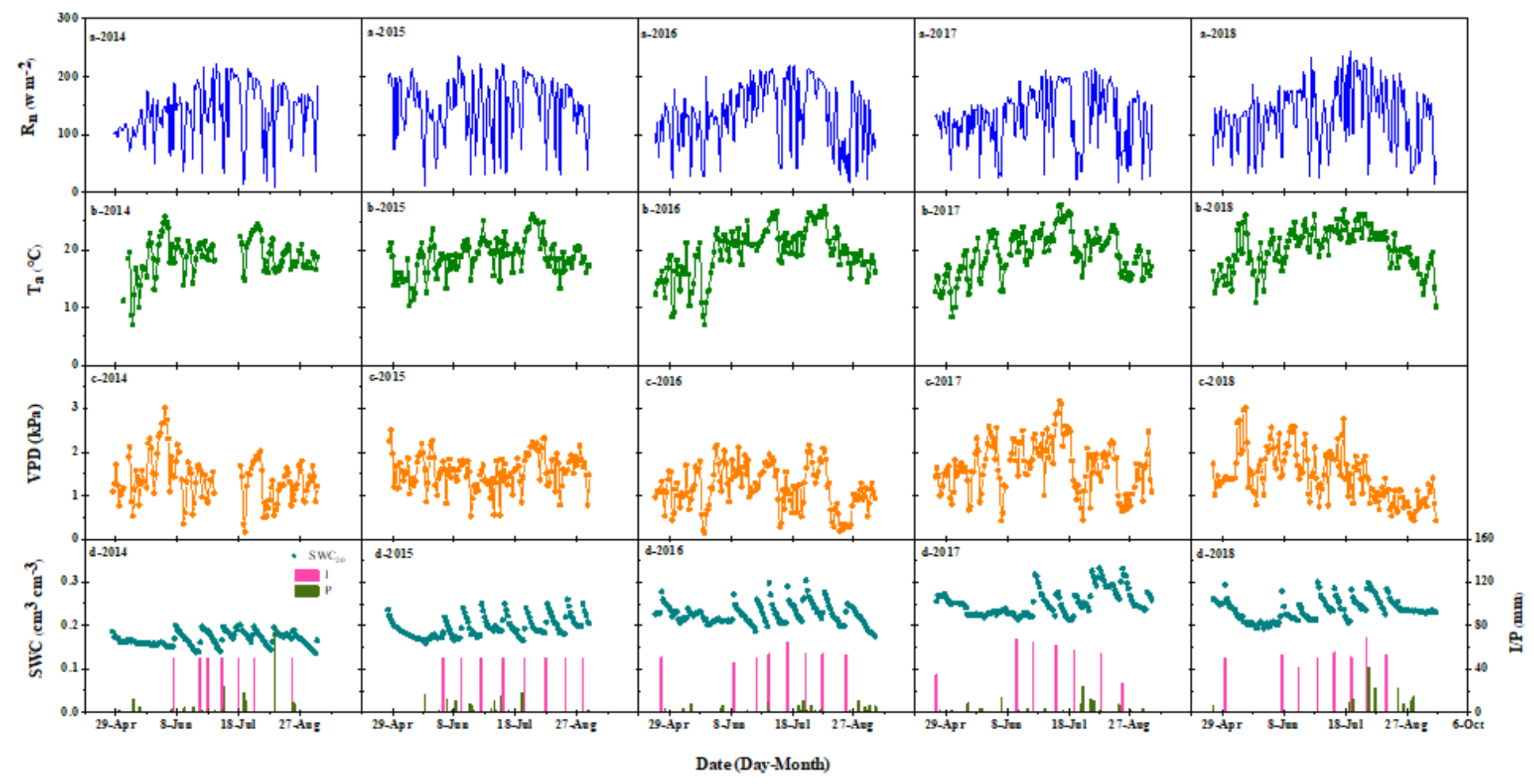

Figure 1

Mean daily values of meteorological factors measured at the experimental sites in growing seasons during 2014-2018: (a) net radiation (Rn), (b) air temperature (Ta), (c) saturated vapor pressure deficit (VPD), (d) soil water content (SWC) and precipitation and irrigation $(\mathrm{P}+\mathrm{l})$ 


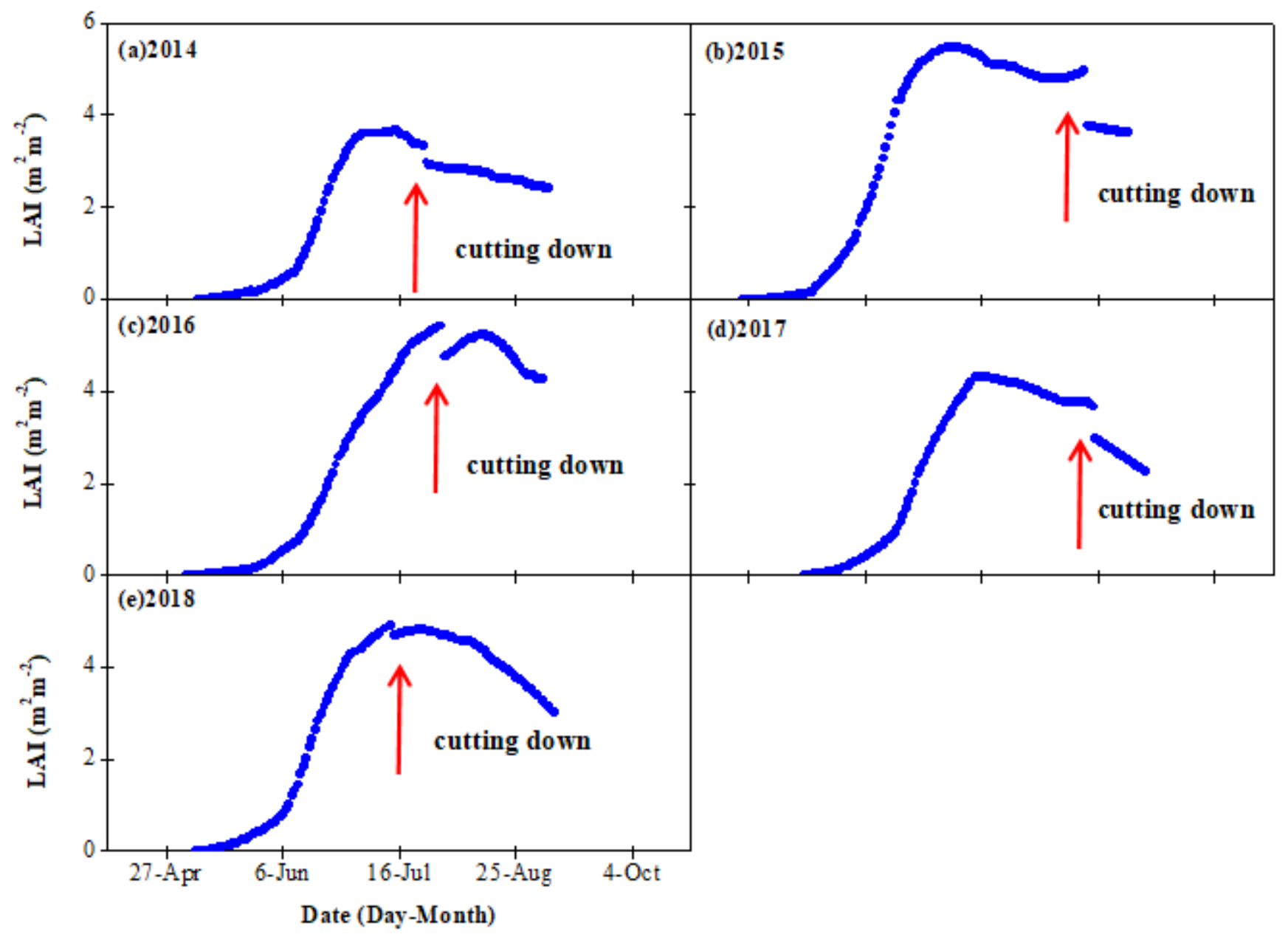

Figure 2

Variations in the leaf area index (CAl) of maize during the growing seasons, 2014-2018 

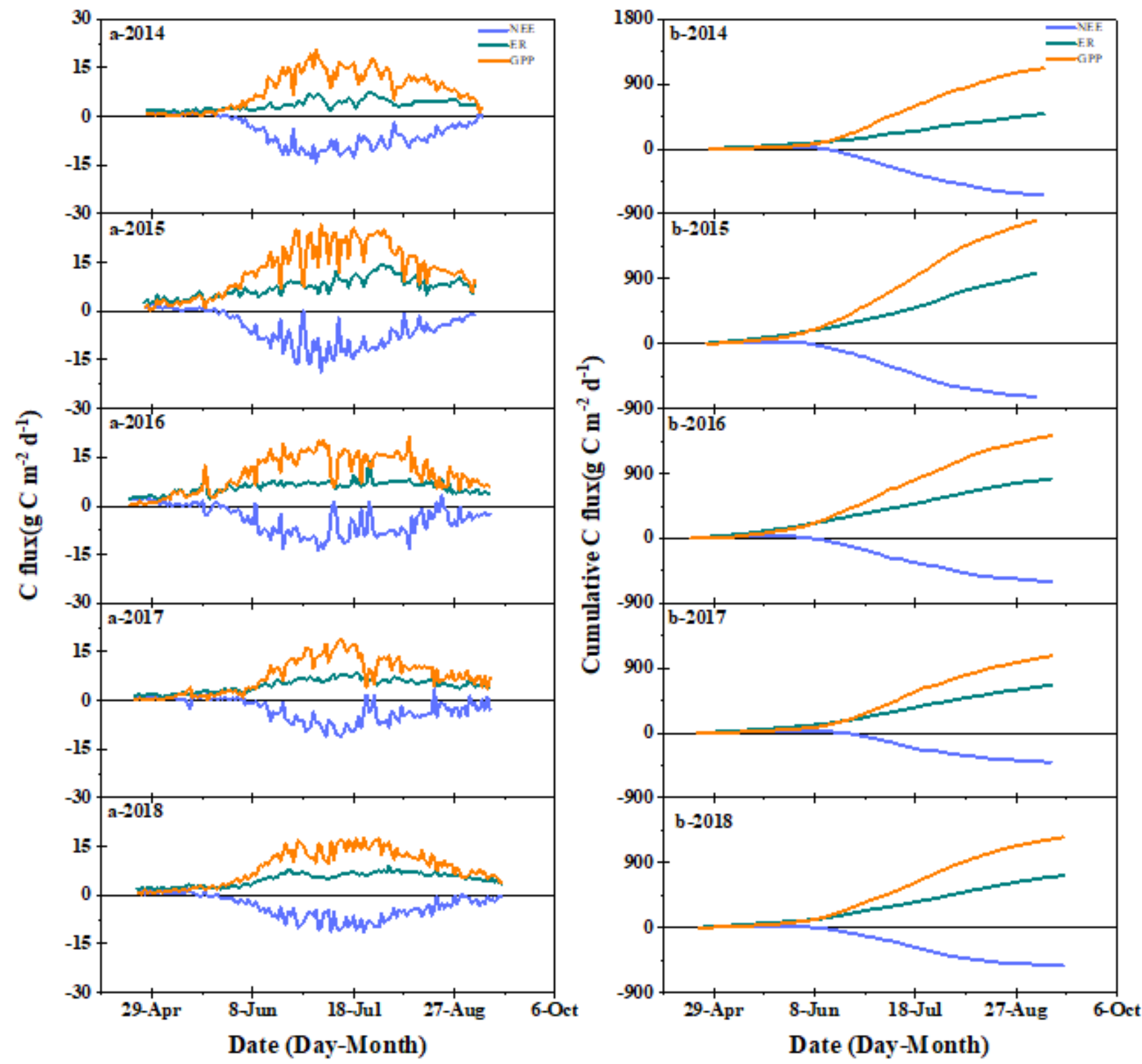

Figure 3

Seasonal fluctuations in daily average (a) net ecosystem exchange (NEE), ecosystem respiration (ER) and gross primary productivity (GPP), (b) the cumulative NEE, ER and GPP over the period of 2014-2018. 


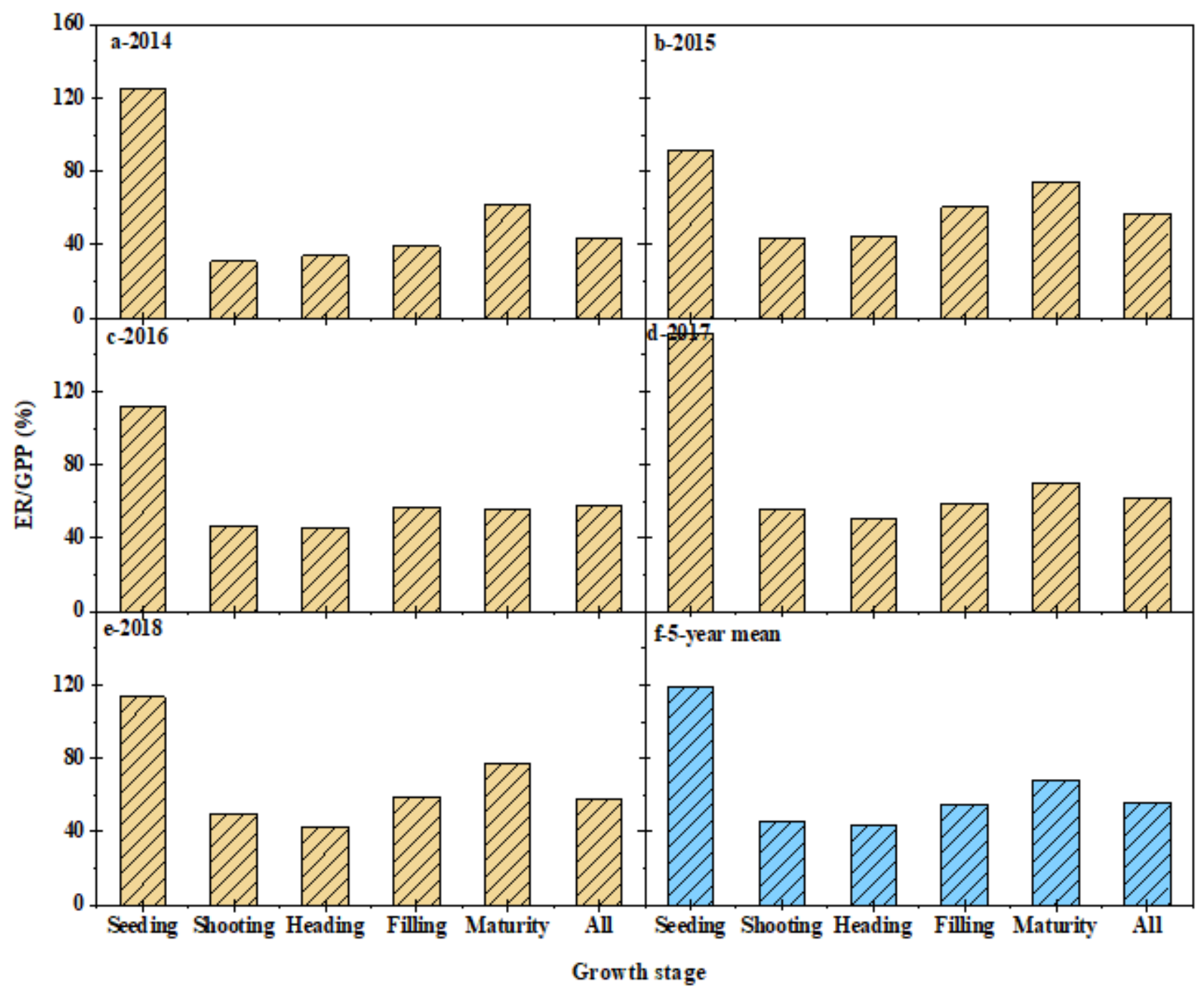

Figure 4

The variation of the ratio of ER/GPP in different growing stages during 2014-2018 


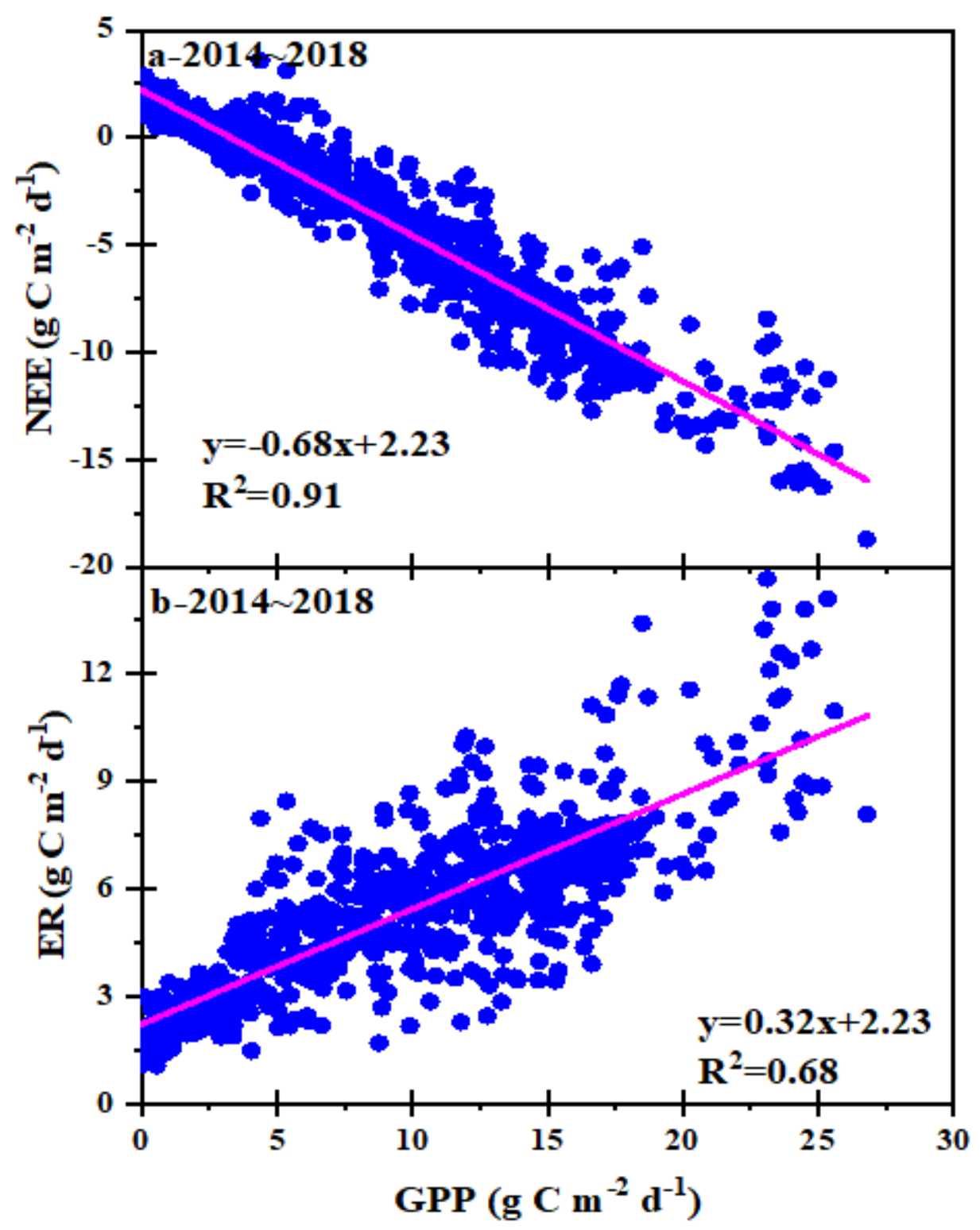

Figure 5

The seasonal variation in ecosystem respiration (ER) and net ecosystem exchange (NEE) in response to gross primary productivity (GPP) during 2014-2018. * represents a significant level $(p<0.001)$. 


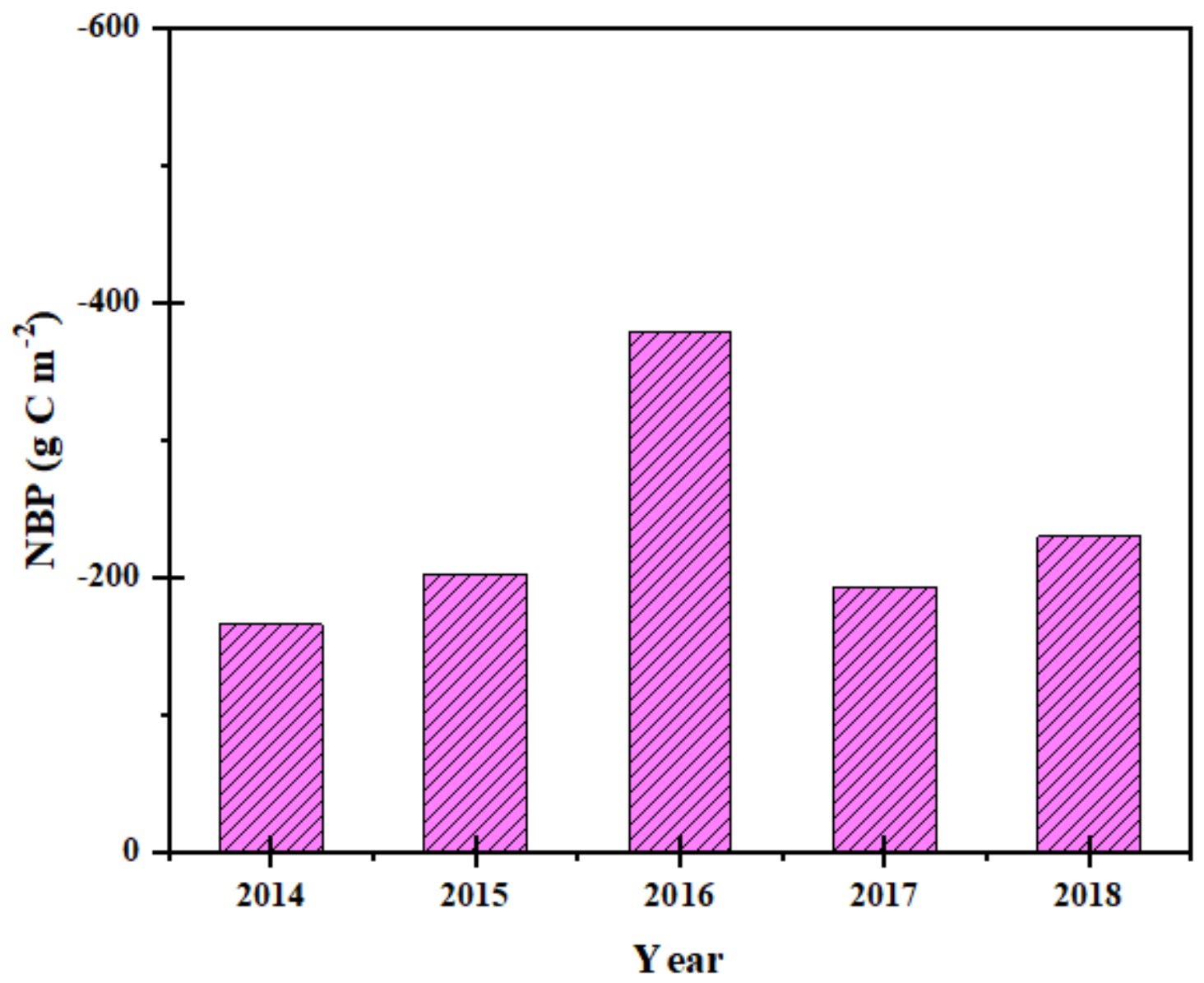

Figure 6

The variation of net biome productivity (NBP) in growing seasons during 2014-2018 

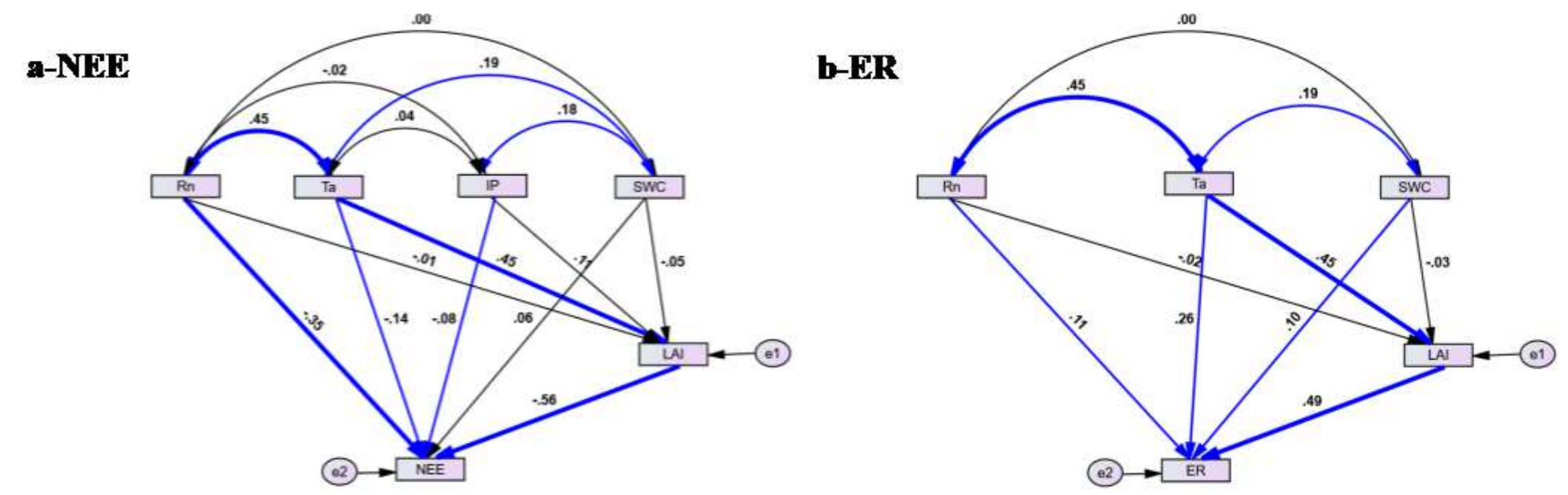

\section{C-GPP}

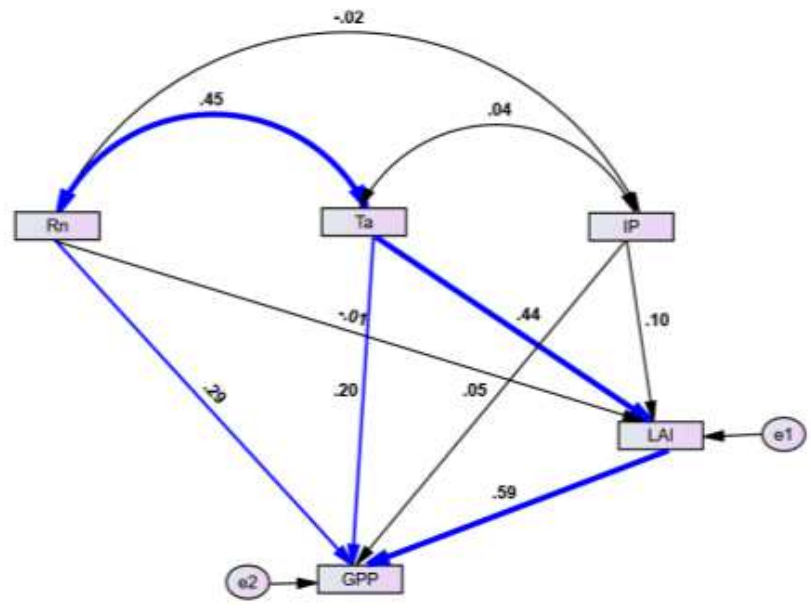

Figure 7

Structural equation models for daily net ecosystem echange (NEE). ecosystem respiration (ER) and gross primary production (GPP) during the growing season in 2014-2018. 